\title{
Gambaran Pelaksanaan Deteksi Dini dan Respon Pandemi COVID-19 di Dinas Kesehatan Kabupaten Pamekasan
}

\section{Implementation of Early Detection and Response to COVID-19 Pandemic at the Pamekasan District Health Office}

\author{
Roza Fitriani*1 $^{1}$, Lucia Yovita Hendrati ${ }^{1}$
}

\begin{abstract}
ABSTRAK
Latar Belakang: Penyakit coronavirus merupakan penyakit baru yang muncul pertama kali di Wuhan, Cina. Kasus menyebar luas hingga menginfeksi lebih dari 13 juta jiwa sampai 13 Juli 2020. Kasus COVID-19 pertama kali dilaporkan di Kabupaten Pamekasan pada 29 Maret 2020. Kasus terus mengalami peningkatan dan terjadi lonjakan kasus positif COVID-19 pada bulan Juni. Hingga 3 Juli 2020, total kasus positif COVID-19 di Kabupaten Pamekasan adalah sebanyak 121 orang dan pada saat itu termasuk dalam kategori wilayah risiko tinggi.

Tujuan: Penelitian ini bertujuan untuk menggambarkan pelaksanaan deteksi dini dan respon COVID-19 di Dinas Kesehatan Kabupaten Pamekasan.

Metode: Penelitian ini dilakukan secara observasional dengan desain penelitian deskriptif. Pengumpulan data diperoleh dari hasil indepth interview kepada satu penanggungjawab surveilans COVID-19 Dinas Kesehatan Kabupaten Pamekasan dan satu petugas surveilans puskesmas yang dipilih secara random sampling. Hasil akan dibandingkan dengan pedoman yaitu Keputusan Menteri Kesehatan Nomor 247 Tahun 2020.

Hasil: Berdasarkan hasil wawancara dan observasi yang dilakukan, deteksi dini dan respon COVID-19 di Dinas Kesehatan Kabupaten Pamekasan dilakukan melalui penguatan jejaring kerja, koordinasi dengan pelayanan kesehatan, penilaian risiko wilayah, pemantauan kasus probable dan konfirmasi positif, penelusuran kontak, pengiriman spesimen, pengadaan logistik, komunikasi risiko, penyelidikan epidemiologi, pengolahan dan analisis data, serta pencatatan dan pelaporan. Namun, pemantauan kasus ILI belum dilakukan untuk penemuan kasus, pengolahan data belum dilakukan secara rutin, dan pelaporan belum sesuai dengan Kepmenkes 247 tahun 2020.

Kesimpulan: Masih terdapat ketidaksesuaian pelaksanaan deteksi dini dan respon COVID-19 di Dinas Kesehatan Kabupaten Pamekasan dengan pedoman yaitu Kepmenkes 247 tahun 2020 sehingga perlu lebih ditingkatkan dan mengikuti pedoman yang ada.
\end{abstract}

Kata kunci: COVID-19, coronavirus, deteksi dini, respon

\begin{abstract}
Background: Coronavirus disease is a new disease that first appeared in Wuhan, China. The case has spread so widely that it has infected more than 13 million people until July 13, 2020. COVID-19 first reported in Pamekasan District on March 29, 2020. Cases continued to increase, and a surge in COVID-19 cases occurred in June. Until July 3, 2020, the total positive patients of COVID-19 in Pamekasan District were 121 people and at that time included in the high-risk area category.

Objectives: This study aims to describe the early detection and response activities for COVID-19 carried out by the Pamekasan District Health Office.

Methods: This research was conducted observational with a descriptive design. Data collection obtained from in-depth interviews with one person in charge of surveillance for COVID-19 at the Pamekasan District
\end{abstract}


Health Office and one surveillance officer selected by random sampling. The results will be compared with the guidelines, namely the Minister of Health Decree Number 247 of 2020.

Results: Early detection and the response of COVID-19 at the Pamekasan District Health Office is carried out through strengthening networks, coordination with health services facilities, regional risk assessment, monitoring of probable and confirmed cases, contact tracing, specimen delivery, procurement of logistics, risk communication, epidemiological investigations, processing and data analysis, recording and reporting case data. However, ILI case monitoring has not been carried out for case finding, data analysis has not been carriedout routinely, and reporting is not in accordance with the Minister of Health Decree 247 of 2020.

Conclusions: The implementation of early detection and response to COVID-19 at the Pamekasan District Health Office is still in conformity with the guidelines, so it needs to be further improved and follow the existing approaches.

Keywords: COVID-19, coronavirus, early detection, response

\author{
*Koresponden: \\ roza.fitriani-2016@fkm.unair.ac.id \\ Roza Fitriani \\ ${ }^{1}$ Departemen Epidemiologi, Fakultas Kesehatan Masyarakat, Universitas Airlangga, Kampus C Mulyorejo, \\ 60115, Surabaya, Jawa Timur, Indonesia
}

\title{
PENDAHULUAN
}

Suatu penyakit infeksi saluran pernapasan seperti pneumonia yang misterius dan belum diketahui etiologinya pertama kali muncul di Kota Wuhan, Provinsi Hubei, Cina pada bulan Desember 2019. Pada 31 Desember 2019, dilaporkan terdapat kluster orang dengan pneumonia yang tidak diketahui penyebabnya ke WHO. Selanjutnya pada 12 Januari 2020, dinyatakan bahwa terdapat sebuah virus corona baru yang awalnya dinamakan 2019 novel coronavirus (2019-nCoV) oleh WHO (WHO, 2020). Virus ini kemudian berganti nama menjadi Severe Acute Respiratory Syndrome Coronavirus 2 (SARS-CoV-2) dan penyakitnya diberi nama Coronavirus Disease 2019 (COVID-19) oleh WHO pada 12 Februari 2020. Pada saat itu kasus telah menyebar luas ke daratan Cina hingga ke negara-negara lain di dunia. Oleh karena itu, pada 11 Maret 2020, WHO mengumumkan bahwa penyakit coronavirus dikategorikan sebagai pandemi (WHO, 2020). Hingga Juli 2020 penyakit coronavirus dilaporkan oleh lebih dari 200 negara dan terus mengalami peningkatan kasus baru setiap harinya. Kasus COVID-19 di dunia hingga 13 Juli 2020 mencapai lebih dari 13 juta jiwa, dengan kasus kematianmencapai lebih dari lima ratus ribu jiwa (Worldometer, 2020).

Penyakit coronavirus pertama kali dilaporkan di Indonesia pada 2 Maret 2020 dan terus mengalami peningkatan hingga 9 Juli 2020 tercatat 70.736 kasus dengan jumlah kematian 3.417 jiwa. Hal ini membuat Indonesia berada pada urutan ke-26 dari seluruh negara di dunia dan merupakan yang tertinggi di Asia Tenggara. Peningkatan kasus paling tinggi terjadi pada 9 Juli 2020 yaitu sebesar 2.657 kasus dalam satu hari. Sejak 26 Juni 2020, Provinsi Jawa Timur menempati urutan pertama kasus COVID-19 tertinggi di Indonesia. Kabupaten Pamekasan menjadi kabupaten yang pertama kali melaporkan kasus COVID-19 di Pulau Madura, Jawa Timur. Kasus pertama kali yang dilaporkan di Kabupaten Pamekasan yaitu pada 29 Maret 2020. Hingga 3 Juli 2020, total kasus positif COVID-19 di Kabupaten Pamekasan adalah sebanyak 121 orang, dengan kasus meninggal sebanyak 22 orang, dan kasus sembuh sebanyak 30 orang (Dinkes Pamekasan, 2020). Pada bulan Juni ini terjadi lonjakan kasus positif baru COVID-19 di Kabupaten Pamekasan yang menempatkan Kabupaten Pamekasan di urutan ke-16 kasus positif tertinggi di Jawa Timur.

Pemerintah Kabupaten Pamekasan melakukan penyelidikan epidemiologi sejak awal adanya kasus COVID-19 sebagai langkah awal penanggulangan. Penyelidikan epidemiologi dilakukan oleh setiap puskesmas yang di wilayahnya terdapat kasus probable maupun kasus konfirmasi COVID-19 yang juga berkoordinasi dengan Dinas Kesehatan Kabupaten. Dinas Kesehatan Kabupaten Pamekasan akan melakukan koordinasi dengan fasyankes di daerahnya termasuk puskesmas dan rumah sakit untuk menemukan kasus. Setiap wilayah mempunyai risiko masing-masing terhadap penularan COVID-19. Menurut perhitungan indikator dari gugus tugas percepatan dan penanganan COVID-19, Kabupaten Pamekasan pada 27 Juni 2020 termasuk dalam kategori zona merah atau risiko tinggi dan menjadi satu-satunya Kabupaten dengan zona merah di Pulau Madura pada saat itu. Hal ini dapat terus berlanjut apabila tidak segera dilakukan penanganan dan pengendalian yang ketat. Analisis pada penelitian ini diperlukan guna mengetahui tindakan respon COVID-19 yang dilakukan oleh Dinas Kesehatan Kabupaten Pamekasan yang kemudian dapat dievaluasi dan diperbaiki agar dapat menerapkan pengendalian yang efektif. Penelitian ini bertujuan untuk menggambarkan upaya deteksi dini dan respon COVID-19 di Dinas Kesehatan Kabupaten Pamekasan. 


\section{METODE}

Penelitian ini termasuk dalam jenis penelitian yang bersifat observasional yaitu peneliti mengamati subjek penelitian berdasarkan pada Kepmenkes 247 tahun 2020, tanpa memberikan perlakuan pada subjek penelitian tersebut. Desain penelitian yang digunakan merupakan penelitian deskriptif yaitu penelitian yang menggambarkan suatu fenomena yang ditemukan. Penelitian ini termasuk dalam penelitian evaluasi, yaitu menilai suatu program yang sedang atau sudah berjalan agar dapat digunakan untuk perbaikan dan peningkatan program. Subjek penelitian ini adalah pelaksanaan deteksi dini dan respon COVID-19. Sumber data yang digunakan adalah data primer dan sekunder. Data primer diperoleh dari hasil indepth interview kepada satu penanggungjawab surveilans COVID-19 Dinas Kesehatan Kabupaten Pamekasan serta satu petugas surveilans puskesmas yang dipilih secara random sampling dengan menggunakan panduan wawancara serta lembar observasi. Sedangkan data sekunder, pengumpulan data melalui laporan harian COVID-19 yang dilaporkan. Hasil selanjutnya dibandingkan dengan pedoman yaitu Keputusan Menteri Kesehatan Nomor 247 Tahun 2020. Hal ini dikarenakan penelitian dilakukan pada bulan Juni 2020 yang pada saat itu menggunakan pedoman Kepmenkes 247 tahun 2020. Hasil tersebut kemudian dinarasikan untuk menjelaskan karakteristik yang tergambar dari variabel yang diteliti. Adanya ketidaksesuaian dengan pedoman tersebut kemudian dapat teridentifikasi dan dapat memberikan suatu saran atau rekomendasi.

\section{HASIL DAN PEMBAHASAN}

\section{Gambaran Deteksi Dini COVID-19 di Dinas Kesehatan Kabupaten Pamekasan Penguatan Jejaring Kerja}

Untuk melakukan deteksi dini dan respon adanya kasus, Dinas Kesehatan Kabupaten Pamekasan melakukan koordinasi dan penguatan jejaring kerja maupun kemitraan kepada lintas program maupun lintas sektor. Dalam melaksanakan hal tersebut, Pemerintah Kabupaten Pamekasan mengadakan rapat pertemuan untuk membentuk tim penanganan COVID-19 di Kabupaten Pamekasan yang juga melibatkan Dinas Kesehatan Kabupaten Pamekasan. Hal yang juga dibahas pada saat itu adalah penyiapan ruangan isolasi di rumah sakit, pengadaan Alat Pelindung Diri (APD), peningkatan kapasitas sumber daya manusia, sosialisasi pada petugas kesehatan, membentuk tim, serta menentukan peran masing-masing petugas. Deteksi dini dilakukan salah satunya melalui penguatan jejaring kerja surveilans dengan lintas program dan lintas sektor (Kepmenkes RI, 2020). Dinkes Pamekasan telah melakukan koordinasi dengan lintas program maupun lintas sektor dalam mengendalikan COVID-19. Hal ini dapat dilihat bahwa pengendalian COVID-19 melibatkan berbagai bidang di Dinkes Pamekasan. Selain itu, sektor yang terkait dalam penanganan wabah ini meliputi BPBD, kepolisian, dan pemerintah daerah. Seperti halnya yang dikemukakan pada penelitian Mitchell et al (2020), bahwa respon terhadap pandemi ini adalah komunikasi dan koordinasi diantara semua pemangku kepentingan. Penting untuk meningkatkan peran masing-masing sektor untuk melakukan pemantauan dan pengawasan berbasis populasi (Mitchell et al., 2020). Oleh karena itu, penguatan jejaring kerja perlu dilakukan agar penanganan COVID-19 termasuk pemantauan kasus dapat lebih terkoordinasi.

\section{Koordinasi dengan Fasilitas Pelayanan Kesehatan}

Sebagai langkah awal pengendalian, fasilitas pelayanan kesehatan seperti puskesmas disiapkan dalam melakukan penanganan COVID-19 termasuk prosedur rujukan kasus probable ke rumah sakit. Petugas surveilans Dinas Kesehatan Kabupaten Pamekasan melakukan pemantauan terhadap pelaksanaan surveilans COVID-19 yang dilakukan oleh puskesmas. Begitu pula di rumah sakit, Dinkes Kabupaten Pamekasan akan melakukan pemantauan terhadap adanya laporan kasus konfirmasi baru dari rumah sakit daerah, yaitu RS Slamet Martodirjo dan RS Noer. Koordinasi antara Dinkes Kabupaten dengan fasilitas pelayanan kesehatan setempat penting dalam melakukan penanganan dan pengendalian COVID-19 yang baik terutama dalam menemukan kasus. Berdasarkan pada Kepmenkes Nomor 247 tahun 2020 tentang Pedoman Pencegahan dan Pengendalian COVID-19, upaya deteksi dini yang juga perlu dilakukan oleh Dinas Kesehatan Kabupaten/Kota adalah memonitor pelaksanaan surveilans COVID-19 yang dilakukan oleh puskesmas serta surveilans rumah sakit untuk menemukan kasus. Hal tersebut telah sesuai dengan yang dilakukan di Dinas Kesehatan Kabupaten Pamekasan dimana dilakukan koordinasi dengan pemantauan terhadap data dari puskesmas secara terus-menerus terutama apabila terdapat kasus konfirmasi positif, termasuk melakukan koordinasi dalam melaksanakan penelusuran kasus probable dan pemeriksaan rapid test. Di rumah sakit Dinkes Pamekasan juga melakukan pemantauan data dan hasil lab dari dua rumah sakit rujukan COVID-19 di wilayahnya. Hal ini juga sesuai dengan penelitian di Mongolia yang menyebutkan bahwa sistem surveilans yang terstruktur untuk pelacakan kontak ditetapkan untuk memungkinkan observasi dan isolasi kontak yang diperlukan untuk menahan penyebaran penyakit (Erkhembayar et al., 2020). Oleh karena itu, koordinasi antara puskesmas, rumah sakit, dan Dinkes Kabupaten melalui surveilans perlu dilakukan dan ditingkatkan dalam upaya menemukan kasus dan mencegah penularan. 


\section{Penilaian Risiko Wilayah}

Penilaian risiko wilayah juga dilakukan dengan menggunakan penilaian 15 indikator dari gugus tugas penanganan COVID-19. Penilaian tersebut dilakukan dengan menggunakan indikator epidemiologi, surveilans, dan pelayanan kesehatan. Data yang digunakan seperti halnya data kasus positif COVID-19, kasus ODP dan PDP, kasus meninggal, sembuh, jumlah pemeriksaan spesimen, dan jumlah tempat tidur RS rujukan. Penilaian risiko ini telah sesuai dengan Kepmenkes 247 tahun 2020. Penilaian risiko sampai dengan 3 Juli 2020 menunjukkan bahwa Kabupaten Pamekasan termasuk dalam zona merah atau risiko tinggi. Penilaian risiko ini dapat berguna dalam menentukan langkah pengendalian dan diterapkan di wilayah tersebut. Seperti halnya pada zona risiko tinggi bentuk implementasi penanganan yang dapat dilakukan diantaranya adalah menjalankan testing yang intensif; penelusuran kontak yang agresif terhadap kasus positif, PDP, dan ODP; masyarakat harus berada di rumah; tidak memperbolehkan perjalanan; dan menutup tempat-tempat umum.

\section{Pemantauan Kasus ILI}

Berdasarkan pedoman, upaya deteksi dini di Dinas Kesehatan Kabupaten/Kota juga dilakukan dengan melakukan pemantauan dan analisis kasus ILI dan pneumonia melalui Sistem Kewaspadaan Dini dan Respon (SKDR). Namun, di Dinas Kesehatan Kabupaten Pamekasan pemantauan terkait SKDR kasus ILI dan pneumonia tidak dilakukan rutin untuk memantau penemuan kasus COVID-19. Website untuk Sistem Kewaspadaan Dini dan Respon (SKDR) yang dapat digunakan dalam mengetahui tren terjadinya penyakit jarang dibuka dan diakses oleh Dinas Kesehatan Kabupaten Pamekasan. Terutama pada masa pandemi COVID-19 ini, website tersebut jarang diakses oleh petugas dikarenakan terdapat petugas surveilans yang mengalami sakit dan SDM menjadi lebih sedikit. Padahal penyakit influenza pneumonia dan COVID-19 merupakan dua jenis pneumonia virus pernapasan dengan manifestasi klinis yang sangat mirip (Shen et al., 2020). Selain itu, ada kemungkinan seseorang tertular infeksi campuran virus influenza dan COVID-19 secara bersamaan (Shen et al., 2020). Menurut CDC, penyakit COVID-19 ringan muncul dengan gejala yang mirip dengan ILI sehingga terdapat Jaringan Pengawasan ILI yang disebut ILINet pada penyedia layanan kesehatan primer dan pusat perawatan gawat darurat di AS. ILINet digunakan untuk melacak tren penyakit COVID-19 ringan hingga sedang dan memungkinkan perbandingan dengan musim influenza sebelumnya (CDC, 2020). Oleh karena itu, perlu dilakukan pendataan kasus pneumonia pada sistem kewaspadaan dini dan respon yang mana juga perlu dilakukan pemantauan untuk mendeteksi secara dini kasus COVID-19.

\section{Gambaran Respon COVID-19 di Dinas Kesehatan Kabupaten Pamekasan Pemantauan Kasus Probable dan Konfirmasi}

Puskesmas mengharuskan bahwa setiap orang yang datang ke wilayah kerja puskesmas maka harus lapor ke RT/RW atau Kepala Dusun. Selanjutnya akan diarahkan oleh satgas desa untuk ke Balai Desa untuk dilakukan pendataan dan pemeriksaan seperti cek suhu, tekanan darah, dan menanyakan keluhan gejala yang dialami. Jika tidak ada keluhan maka dinamakan ODR (Orang Dalam Risiko) dan akan dilakukan pemantauan selama 14 hari. Jika saat pemantauan selama 14 hari menunjukkan adanya gejala dan terdapat keluhan seperti demam, batuk, maupun pilek maka akan dikategorikan sebagai ODP (Orang Dalam Pemantauan). Petugas surveilans puskesmas akan melakukan pemantauan pada kasus ODP selama 14 hari menggunakan formulir yang telah disediakan dengan melakukan komunikasi melalui telepon atau WhatsApp. Petugas surveilans di tingkat puskesmas melakukan pemantauan kasus positif dan probable COVID-19 dengan bantuan bidan desa, perawat, dan juga kader. Kader akan melaporkan ke bidan desa dan bidan desa melakukan pelaporan ke petugas penanggungjawab surveilans di puskesmas. Petugas surveilans di puskesmas akan melaporkan kasus baru kepada petugas surveilans di Dinas Kesehatan Kabupaten sehingga pemantauan kasus yang berjalan di Dinkes Kabupaten bersifat pasif.

Berdasarkan pada Kepmenkes Nomor 247 tahun 2020 tentang Pedoman Pencegahan dan Pengendalian COVID-19, respon yang dilakukan oleh Dinkes Kabupaten/Kota dapat dibedakan menjadi respon terhadap kasusPDP (Pasien Dalam Pengawasan), ODP (Orang Dalam Pengawasan), dan OTG (Orang Tanpa Gejala). Namun, diantara semua respon tersebut terdapat kesamaan respon yang dilakukan. Respon yang dilakukan Dinas Kesehatan Kabupaten/Kota menurut Kepmenkes tersebut adalah dengan melakukan koordinasi dengan puskesmas terkait pemantauan harian kasus. Berdasarkan penelitian Djalante et al (2020), pemerintah perlu memperkuat sistem perawatan kesehatan primer dan memfasilitasi respon berbasis komunitas COVID-19 dalam melakukan pemantauan. Dinas Kesehatan Kabupaten Pamekasan juga telah melakukan pemantauan harian terkait kasus probable (ODP dan PDP) serta kasus positif dari laporan-laporan yang dikirim oleh puskesmas. Pemantauan data ini lebih bersifat pasif yang mana Dinkes Kabupaten hanya menerima informasi dari puskesmas. Surveilans pasif artinya hanya melakukan pemantauan penyakit berdasarkan laporan yang tersedia di fasilitas pelayanan kesehatan. Surveilans ini lebih mudah dilakukan, namun seringkali ketepatan dan kelengkapan laporannya cenderung rendah. Oleh karena itu, lebih baik dilakukan pemantauan dengan mengkombinasikan antara surveilans aktif dan surveilans pasif. Menurut penelitian di Cina, upaya pencegahan juga dapat dilakukan melalui pemantauan secara aktif dengan melibatkan organisasi masyarakat (Liu et al., 2020). Kedepannya diharapkan petugas dapat melakukan 
pemantauan secara langsung ke fasilitas pelayanan kesehatan dan melakukan crosscheck keakuratan data yang dilaporkan ke Dinkes Kabupaten. Pemantauan juga dapat dilakukan dengan melibatkan organsisasi masyarakat.

\section{Penelusuran Kontak Erat}

Respon yang juga dilakukan menurut Kepmenkes No.247 tahun 2020 oleh Dinkes Kabupaten adalah koordinasi dengan puskesmas terkait pemantauan kontak. Kasus yang terkonfirmasi positif akan diinformasikan oleh satgas maupun Dinkes Kabupaten kepada puskesmas untuk selanjutnya meminta puskesmas agar segera melakukan Penyelidikan Epidemiologi (PE) ke rumah kasus dan melakukan pencarian kontak kasus (contact tracing) seperti keluarga maupun rekan kerja yang selanjutnya dilakukan edukasi untuk isolasi di rumah. Setelah dilakukan PE maka dalam beberapa hari kemudian akan dilakukan rapid test terhadap kontak erat. Jika hasilnya non reaktif, maka kontak erat tersebut akan masuk kategori ODR. Jika hasilnya reaktif, akan dilakukan rapid test ulang maupun dilakukan pengambilan swab. Pengambilan swab dilakukan dengan merujuk kontak erat tersebut ke rumah sakit. Puskesmas akan melakukan koordinasi dengan rumah sakit dan mendaftarkan kasus probable tersebut. Kontak erat ini tetap dianjurkan untuk melakukan isolasi mandiri di rumah dan menjaga kontak dengan orang lain. Hal ini sesuai dengan yang dikemukakan oleh WHO bahwa identifikasi kontak dilakukan melalui wawancara dengan orang yang terinfeksi COVID-19 untuk mengetahui dengan siapa mereka telah melakukan kontak (WHO, 2020). Informasi yang diperoleh dari pelacakan kontak ini dapat mengetahui bagaimana penyakit menyebar dari orang ke orang dan mengetahui rantai infeksi (CDC, 2020). Kontak ini kemudian dianjurkan untuk tetap melakukan karantina, yaitu memisahkan diri dari orang lain untuk membatasi kemungkinan orang lain menjadi terinfeksi apabila kontak tersebut benar-benar mengalami sakit (WHO, 2020). Kontak orang dengan COVID-19 ini berisiko lebih tinggi untuk mengembangkan penyakit dan menyebarkan ke orang lain (CDC, 2020). Pelaksanaan pelacakan kontak dapat dilakukan secara ketat agar dapat membantu memperlambat penyebaran COVID-19.

\section{Pengambilan dan Pengiriman Spesimen}

Pemeriksaan swab pada kontak erat kasus positif akan dilakukan oleh petugas puskesmas di rumah sakit. Petugas puskesmas yang melakukan swab di rumah sakit dilakukan secara bergantian dan akan dijadwalkan terlebih dahulu oleh rumah sakit terkait tanggal pengambilan swab serta petugas yang akan melakukan pengambilan swab. Dari 20 puskesmas yang ada di Kabupaten Pamekasan akan dijadwalkan secara bergantian dan biasanya pengambilan swab dilakukan pada hari Senin, Rabu, dan Kamis. Selanjutnya, spesimen tersebut akan dilakukan pengiriman ke laboratorium di Surabaya seperti BBTKLPP atau laboratorium RSUD Dr.Soetomo Surabaya. Spesimen dari RS Slamet Martodirjo Pamekasan akan dikirimkan oleh petugas Dinas Kesehatan Kabupaten Pamekasan ke Surabaya. Sedangkan untuk RS Noer tidak memerlukan pengiriman ke laboratorium di Surabaya karena pemeriksaan COVID-19 dilakukan sendiri dengan menggunakan TCM. Biasanya petugas yang bertugas melakukan pengiriman spesimen terdiri dari dua petugas. Pengiriman spesimen ke Surabaya dilakukan pada hari Selasa, Kamis, dan Jumat. Hal tersebut telah sesuai dengan Kepmenkes nomor

247 tahun 2020, dimana perlu dilakukan koordinasi dengan rumah sakit serta laboratorium dalam hal pengambilan dan pengiriman spesimen. Menurut penelitian Djalante et al (2020), hal yang perlu dilakukan dalam penanganan COVID-19 adalah mengkoordinasikan dan memanfaatkan semua laboratorium PCR baik pada lembaga penelitian, rumah sakit, klinik, dan pemerintah daerah untuk mendukung diagnosis berbasis PCR. Di Kabupaten Pamekasan, pemeriksaan spesimen dilakukan dengan melibatkan pihak puskesmas, rumah sakit, dinkes setempat, dan laboratorium. Koordinasi ini telah berjalan dengan baik termasuk jadwal pengambilan swabyang dilakukan puskesmas dan jadwal pengiriman spesimen yang dilakukan oleh Dinkes Pamekasan. Diharapkan pemeriksaan spesimen swab nasofaring dapat ditingkatkan dan dilakukan secara masif sehingga kasus dapat segera terdeteksi dan dilakukan pencegahan.

\section{Pengadaan Logistik}

Pengadaan logistik dilakukan dengan perhitungan dan pemesanan APD maupun rapid test kit. Logistik ini selanjutnya dapat didistribusikan ke puskesmas-puskesmas maupun rumah observasi. Dinkes Kabupaten Pamekasan melakukan penyediaan rapid test sebagai upaya skrining COVID-19. Puskesmas yang membutuhkan pemeriksaan rapid test pada masyarakat di wilayah kerjanya perlu mengajukan surat permohonan permintaan logistik rapid test kepada Dinkes Kabupaten Pamekasan. Surat yang masuk akan diproses terlebih dahulu dan mempertimbangkan persetujuan dari Kepala Bidang P2P. Pengajuan permintaan rapid test yang telah diterima akan diteruskan kepada petugas untuk selanjutnya mendistribusikan alat rapid test kepada puskesmas yang membutuhkan. Hal ini telah sesuai dengan Kepmenkes 247 tahun 2020, dimana respon yang juga perlu dilakukan adalah memobilisasi sumber daya yang dibutuhkan termasuk logistik laboratorium. Dinkes melakukan pengadaan logistik melalui permintaan ke Provinsi sampai logistik datang dan dilakukan penyimpanan di gudang. Logistik tersebut kemudian akan dimobilisasi ke fasyankes yang membutuhkan terutama pada puskesmas maupun intansi lain yang membutuhkan. Selain itu, Dinkes 
Kabupaten Pamekasan seringkali menyediakan rapid test gratis kepada masyarakat di daerah yang berisiko. Seperti halnya rapid test gratis yang dilakukan pada wartawan, santri, lembaga pemerintahan, dan di pasarpasar yang ada di Kabupaten Pamekasan. Petugas yang melakukan rapid test adalah petugas puskesmas. Dinkes Pamekasan hanya menyediakan logistik serta supervisi. Namun, seringkali petugas dari Dinkes yang juga langsung melakukan pemeriksaan rapid test sendiri ke institusi pemerintahan.

\section{Komunikasi Risiko pada Masyarakat}

Edukasi kepada masyarakat dilakukan oleh bagian promosi kesehatan dengan menyebarkan brosur, membuat poster dan spanduk yang ditempel di lingkungan Dinas Kesehatan terkait upaya pencegahan penularan COVID-19. Dinkes Kabupaten Pamekasan juga melakukan komunikasi risiko yang mana hal tersebut dilakukan oleh Kepala Dinkes kepada semua petugas Dinkes untuk selanjutnya dapat disebarluaskan kepada masyarakat. Selain itu, saat pelaksanaan penyelidikan biasanya juga akan dilakukan komunikasi risiko kepada kasus probable maupun kontak erat terkait informasi COVID-19. Hal ini telah sesuai dengan Kepmenkes 247 tahun 2020, yang mana salah satu responnya adalah melakukan komunikasi risiko kepada masyarakat serta edukasi terhadap kasus ODP maupun OTG untuk isolasi diri di rumah dan apabila mengalami perburukan gejala segera ke fasyankes (Kepmenkes RI, 2020). Pada masa yang tidak stabil seperti pandemi saat ini, keadaan dapat berubah dan informasi berkembang dengan cepat sehingga fokus penanganan juga pada peran komunikasi risiko yang tepat dan efektif (Abrams dan Greenhawt, 2020). Upaya komunikasi risiko oleh Dinkes Pamekasan juga dilakukan melalui platform media sosial seperti Youtube, Instagram, Facebook, dan broadcast WhatsApp. Berdasarkan penelitian di Kanada, mengemukakan bahwa salah satu cara potensial untuk memastikan komunikasi risiko yang tepat adalah melalui penggunaan media sosial, karena publik sangat bergantung pada media dan hubungan sosial untuk menginformasikan tingkat persepsi risiko mereka (Abrams dan Greenhawt, 2020). Ini juga memungkinkan pesan untuk tersebar lebih luas pada masyarakat umum. Hal terpenting lainnya dalam komunikasi risiko adalah melibatkan pemangku kepentingan dalam penyampaian pesan kesehatan masyarakat (Abrams dan Greenhawt, 2020). Komunikasi risiko diharapkan dapat terus dilakukan secara luas ke masyarakat dalam bentuk media online maupun offline.

\section{Penyelidikan Epidemiologi}

Apabila terdapat warga yang dikategorikan sebagai orang yang berisiko, ODP, maupun PDP, petugas surveilans puskesmas akan melakukan yang dinamakan Penyelidikan Epidemiologi (PE). Tim yang melakukan PE adalah petugas surveilans puskesmas, bidan desa, dan perangkat/satgas desa. Pada awal adanya kasus Dinkes Kabupaten Pamekasan juga turut serta melakukan PE. Penyelidikan lapangan dapat menunjukkan kasus yang mungkin terinfeksi, kapan mulai sakit, dan dimana mereka berada sebelum sakit (CDC, 2020). Hal yang dipersiapkan dalam melakukan PE adalah form penyelidikan epidemiologi, alat tulis kantor, alat pemeriksa suhu tubuh, alat pelindung diri seperti handscoon, masker, face shield, dan baju hazmat (jika melakukan PE pada keluarga kasus positif). Petugas yang melakukan PE akan menanyakan beberapa hal yang terdapat pada formulir penyelidikan kepada kontak erat. Begitupun kepada kasus konfirmasi positif yang berada di rumah dan belum mengetahui bahwa statusnya positif COVID-19. Petugas akan melakukan PE dan menyampaikan hasil pemeriksaan lab serta menanyakan kepada kasus terkait apakah kasus bersedia melakukan perawatan di rumah sakit atau isolasi mandiri di rumah. Hal ini juga telah sesuai dengan Kepmenkes 247 tahun 2020 yaitu melakukan penyelidikan epidemiologi yang berkoordinasi dengan puskesmas. Namun, PE ini dilakukan hanya pada saat awal mula adanya kasus konfirmasi, seiring bertambahnya kasus COVID-19 di Kabupaten Pamekasan, pelaksaan PE ini sepenuhnya dilakukan oleh puskesmas. Dinkes Pamekasan hanya menerima laporan hasil PE dari puskesmas dan melakukan pemantauan lebih lanjut. Menurut penelitian di Cina, investigasi epidemiologi dan manajemen kontak dekat dapat dilakukan melalui kerja sama komunitas (Liu et al., 2020). Diharapkan petugas Dinkes Kabupaten dapat turut serta melakukan penyelidikan epidemiologi bersama dengan puskesmas ataupun melakukan supervisi terhadap pelaksanaan PE dari setiap puskesmas secara berkala.

\section{Pengolahan dan Analisis Data}

Data kasus positif COVID-19 yang terkumpul di Dinas Kesehatan Kabupaten Pamekasan dilakukan pengolahan melalui aplikasi komputer yang disajikan dalam bentuk tabel dan grafik. Data yang sudah diolah akan menghasilkan deskripsi kasus menurut orang, tempat, dan waktu. Namun, pengolahan data COVID-19 di Dinkes Pamekasan belum dilakukan secara optimal dan rutin. Hal ini dapat dilihat bahwa setiap harinya pengolahan data belum dilakukan secara rutin padahal jumlah kasus COVID-19 terus mengalami perubahan setiap harinya. Data kasus sampai bulan Mei 2020 tidak dilakukan pengolahan dan analisis, hanya berbentuk data mentah saja.

Untuk hasil pelaksanaan penyelidikan epidemiologi (PE) seharusnya juga dilakukan pengolahan data. Meskipun Dinas Kesehatan Kabupaten tidak turun langsung melakukan PE, namun petugas dari puskesmas maupun rumah sakit seringkali melakukan pengiriman form hasil PE ke Dinkes Kabupaten. Form ini dapat direkap ulang terutama pada kasus konfirmasi positif untuk dapat mendata informasi klinis seperti 
gejala dan penyakit penyerta serta faktor risiko seperti riwayat perjalanan dan riwayat kontak. Namun, di Dinas Kesehatan Kabupaten Pamekasan belum dilakukan pengolahan data lebih lanjut terhadap data hasil PE tersebut. Hal ini dikarenakan pada saat awal pandemi COVID-19, petugas surveilans Dinkes Kabupaten yang bertanggungjawab dalam penanganan COVID-19 mengalami sakit sehingga tugasnya dilimpahkan kepada petugas lain yang membuat beban kerja petugas tersebut meningkat. Selain itu, adanya rangkap tugas membuat petugas surveilans Dinkes Kabupaten juga tidak mempunyai cukup waktu untuk melakukan pengolahan dan analisis data terutama untuk kasus COVID-19.

Menurut CDC, ketika kasus COVID-19 dilaporkan maka perlu dilakukan pengawasan kesehatan masyarakat, pengumpulan data yang sistematis, analisis, dan interpretasi data kesehatan (CDC, 2020). Dinas Kesehatan Kabupaten Pamekasan menerima laporan PE yang merupakan formulir yang digunakan saat PE dari puskesmas. Namun, form tersebut seringkali tidak dilakukan perekapan ulang. Akan lebih baik apabila form PE yang diterima dilakukan pendataan dan perekapan ulang untuk mengetahui informasi gejala dan komorbid dari kasus dan informasi lain yang terdapat pada formulir. Data yang telah dikumpulkan dapat diolah dengan baik dan akan memberikan informasi spesifik terkait gambaran suatu penyakit. Data yang dikumpulkan dan dipantau dari waktu ke waktu dapat mendukung deteksi tren menurut orang, tempat, dan waktu (Groseclose dan Buckeridge, 2017). Analisis data yang andal dapat memberikan informasi relevan yang memungkinkan pelaksanaan intervensi kesehatan masyarakat yang tepat (Frimpong et al., 2017). Oleh karena itu, data yang diperoleh dari hasil penyelidikan maupun data harian lainnya perlu dilakukan pengolahan secara rutin untuk memperoleh informasi epidemiologi yang berguna dalam pengambilan keputusan. Hal ini dapat ditingkatkan melalui adanya pelatihan kepada petugas surveilans dalam melakukan analisis data terutama untuk COVID-19 ataupun melalui pemberian reward kepada petugas yang rutin melakukan analisis data.

\section{Pencatatan dan Pelaporan}

Rumah sakit yang melakukan pengambilan spesimen swab, biasanya juga melakukan pencatatan data melalui aplikasi online All Record TC-19. Spesimen yang diambil dan dikirim ke laboratorium harus dicatat dan dilaporkan pada aplikasi All Record TC-19. Dinas Kesehatan Kabupaten/Kota juga dapat memantau data yang telah masuk situs All Record TC-19 dan melakukan pengumpulan data terkait kasus dengan konfirmasi lab positif COVID-19 yang selanjutnya akan dilaporkan. Selain itu, laporan harian terkait perkembangan kasus probable dan konfirmasi COVID-19 juga dilaporkan oleh masing-masing puskesmas melalui komunikasi secara online. Puskesmas akan mengirimkan data harian meliputi jumlah kasus probable dan konfirmasi positif COVID-19, kasus probable yang sedang dipantau, kasus probable yang selesai dipantau, kasus probable yang meninggal, kasus konfirmasi positif yang meninggal, dan kasus konfirmasi positif yang sembuh. Puskesmas perlu mengirimkan sampai dengan batas waktu yang ditentukan Dinkes Kabupaten yaitu pukul 11.00 WIB melalui WhatsApp pada petugas surveilans Dinkes Kabupaten. Namun, seringkali data yang masuk mengalami keterlambatan ataupun salah input data. Dinkes Kabupaten Pamekasan akan melakukan pelaporan secara online kepada Dinkes Provinsi dengan batas waktu sampai pukul 13.00 WIB. Pelaporan ini meliputi jumlah kasus saja. Data yang terlambat dilaporkan ke Dinkes Kabupaten akan dilaporkan keesokan harinya oleh Dinkes Kabupaten kepada Dinkes Provinsi.

Berdasarkan Kepmenkes 247 tahun 2020, respon oleh Dinkes Kabupaten/Kota juga dilakukan melalui pelaporan 1x24 jam secara berjenjang ke Dinkes Provinsi menggunakan formulir 4 dan 5 . Form 4 berisikan laporan harian data kasus COVID-19 yang dilakukan pemeriksaan spesimen yang meliputi nama, umur, alamat, tanggal gejala, gejala, tanggal ambil spesimen, dan lab pemeriksa. Sedangkan form 5 berisikan laporan harian penemuan kasus konfirmasi, PDP, ODP, dan OTG yang diisi dengan jumlah kasus baru, jumlah kasus baru dan lama, jumlah yang dipantau, jumlah yang selesai dipantau, dan jumlah yang masih di isolasi/karantina di RS rujukan, RS darurat, atau mandiri di rumah. Pelaporan kasus dilakukan oleh Dinkes Kabupaten Pamekasan, namun dengan menggunakan form 5 saja, yaitu berdasarkan pada jumlah saja bukan identitas pasien seperti yang terlampir pada formulir 4. Menurut CDC, pengawasan bukan hanya tentang menghitung kasus, namun semua jenis informasi dapat dikumpulkan untuk mempelajari penyakit (CDC, 2020). Sistem pelaporan perlu mempunyai kelengkapan yang tinggi sebagai bukti dalam pengambilan kebijakan. Pelaporan identitas pasien dapat berguna dalam mengetahui karakteristik kasus berdasarkan wilayah provinsi maupun nasional. Oleh karena itu, Dinkes Kabupaten Pamekasan perlu melakukan pencatatan yang baik dan pelaporan terkait laporan harian kasus yang meliputi identitas pasien, tanggal onset, gejala, dan tanggal ambil spesimen dengan melakukankoordinasi yang baik dengan fasyankes.

Selain itu, berdasarkan Kepmenkes nomor 247 tahun 2020, untuk kasus PDP dilakukan pencatatan dan pelaporan hasil pemantauan harian secara rutin menggunakan formulir 2 dan 3. Sedangkan untuk kontak erat (OTG) dilakukan pendataan menggunakan formulir 13. Formulir 2 merupakan formulir pemantauan harian yang digunakan untuk ODP, OTG, dan PDP ringan. Formulir 3 merupakan formulir pemantauan petugas kesehatan di KKP/Fasyankes (RS, Puskesmas, dll) terhadap kasus ISPA, pneumonia, dan pneumonia berat. Pada Dinkes Kabupaten Pamekasan, pencatatan dan pelaporan hasil pemantauan seperti yang terdapat pada formulir 3 belum dilakukan, sedangkan pencatatan pada formulir 2 biasanya dilakukan oleh puskesmas yang selanjutnya dilaporkan ke Dinkes Kabupaten. Pemantauan terhadap petugas kesehatan perlu dilakukan 
pencatatan pula karena petugas kesehatan seperti dokter dan perawat merupakan profesi yang menghabiskan banyak waktu dalam memberikan perawatan kepada pasien COVID-19 (Jackson et al., 2020). Pandemi COVID-19 ini menyebabkan kematian yang belum pernah terjadi sebelumnya diantara perawat dan dokter yang menandakan pentingnya dilakukan pemantauan dan peningkatan keselamatan kerja bagi perawat, dokter, dan semua petugas kesehatan (Jackson et al., 2020). Oleh karena itu, penting untuk melaksanakan pemantauan yang ketat pada petugas kesehatan dan pengawasan tempat kerja dalam memastikan kesehatan petugas kesehatan.

Formulir 13 merupakan formulir pendataan kontak (contact listing) yang berisikan identitas kontak, kategori kontak, tanggal kontak, hubungan dengan kasus, APD yang dipakai, dan durasi kontak. Pada Dinkes Kabupaten Pamekasan tidak terdapat pendataan kontak seperti yang tercantum dalam formulir 13. Pendataan kontak dilakukan oleh puskesmas menggunakan formulir pelacakan kontak erat dan hasilnya dikirim ke Dinkes Kabupaten. Namun, tidak dilakukan pendataan lebih lanjut oleh Dinkes Kabupaten Pamekasan. Menurut penelitian Djalante et al (2020), hal yang perlu dilakukan untuk menekan perkembangan virus adalah mengidentifikasi dan memetakan setiap orang yang terinfeksi dengan kontak dekat akan sangat membantu dalam pelacakan kontak. Respons yang efektif dimulai dengan pelaporan penyakit dan pemantauan wabah yang tersentralisasi (Mitchell et al., 2020). Menurut CDC, perlu dilakukan pelacakan kasus dan mengumpulkan informasi tentang penyakit dari sistem pengawasan yang melaporkan berbagai jenis data seperti informasi demografis (usia atau jenis kelamin) dan gejala (CDC, 2020). Oleh karena itu, perlu dilakukan pendataan secara rinci terkait kontak-kontak erat diantara kasus positif agar dapat mudah dipantau.

\section{KESIMPULAN}

Pelaksanaan deteksi dini dan respon COVID-19 di Dinas Kesehatan Kabupaten Pamekasan telah sesuai dengan Kepmenkes 247 tahun 2020. Namun, masih terdapat beberapa hal yang belum sesuai diantaranya adalah pemantauan terhadap kasus ILI (Influenza Like Illness) tidak dilaksanakan, penyelidikan epidemiologi hanya dilakukan oleh puskesmas, analisis data tidak dilakukan secara rutin, pelaporan hanya berdasarkan jumlah, dan tidak terdapat pendataan kontak serta pemantauan petugas kesehatan. Oleh karena itu penting untuk dilakukan pemantauan terhadap kasus ILI melalui Sistem Kewaspadaan Dini dan Respon, supervisi terhadap pelaksanaan penyelidikan epidemiologi oleh puskesmas, pemberian pelatihan maupun reward kepada petugas yang rutin melakukan analisis data, pendataan kontak erat dan petugas kesehatan yang berisiko, serta meningkatkan kelengkapan pelaporan sesuai dengan pedoman.

\section{ACKNOWLEDGEMENT}

Peneliti berterimakasih kepada semua pihak yang telah terlibat pada penelitian yang saya lakukan ini, saya berharap semoga informasi yang tertuang didalam artikel ini dapat berguna bagi pembaca.

\section{REFERENSI}

Abrams, E. M. dan Greenhawt, M. (2020) 'Risk Communication During COVID-19', The Journal of Allergy and Clinical Immunology. In Practice, 8(8), pp. 1791-1794. doi: 10.1016/j.jaip.2020.04.012.

CDC (2020) Cases, Data, and Surveillance, Centers for Disease Control and Prevention. Available at: https://www.cdc.gov/coronavirus/2019-ncov/cases-updates/index.html (Accessed: 9 August 2020).

CDC (2020) COVIDView: A Weekly Surveillance Summary of U.S. COVID-19 Activity. U.S. Availableat: https://www.cdc.gov/coronavirus/2019-ncov/covid-data/covidview/index.html.

Dinkes Pamekasan (2020) Laporan Harian COVID-19 di Kabupaten Pamekasan. Pamekasan: Dinas Kesehatan Kabupaten Pamekasan.

Djalante, R., Lassa, J., Setiamarga, D., Sudjatma, A., Indrawan, M., Haryanto, B., Mahfud, C., Sabaruddin, M., Djalante, S., Ra, I., Adi, L., Ayu, G., Surtiari, K., dan Warsilah, H. (2020) 'Review and Analysis of Current Responses to COVID-19 in Indonesia: Period of January to March 2020', Progress in Disaster Science, 6. doi: 10.1016/j.pdisas.2020.100091.

Erkhembayar, R., Dickinson, E., Badarch, D., Narula, I., Thomas, G. N., Ochir, C., dan Manaseki- Holland, S. (2020) 'Early policy actions and emergency response to the COVID-19 pandemic in Mongolia: experiences and challenges', The Lancet Global Health. The Author(s). Published by Elsevier Ltd. This is an Open Access article under the CC BY 4.0 license, (20). doi: 10.1016/s2214109x(20)30295-3.

Frimpong, J. A., Park, M. M., Amo-Addae, M. P., Adewuyi, P. A., dan Nagbe, T. K. (2017) 'Detecting, Reporting, and Analysis of Priority Diseases for Routine Public Health Surveillance in Liberia', The Pan African medical journal, 27(Supp 1), p. 9. doi: 10.11604/pamj.supp.2017.27.1.12570. 
Groseclose, S. L. dan Buckeridge, D. L. (2017) 'Public Health Surveillance Systems: Recent Advances in Their Use and Evaluation', Annual Review of Public Health, 38, pp. 57-79. doi: 10.1146/annurevpublhealth-031816-044348.

Jackson, D., Anders, R., Padula, W. V., Daly, J., dan Davidson, P. M. (2020) 'Vulnerability of Nurse and Physicians with COVID-19: Monitoring and Surveillance Needed', Journal of Clinical Nursing, pp. 1-4. doi: 10.1111/jocn.15347.

Kepmenkes RI (2020) Keputusan Menteri Kesehatan RI Nomor 247 Tahun 2020 Tentang Pedoman Pencegahan dan Pengendalian Coronavirus Disease 2019 (COVID-19). Jakarta.

Mitchell, S. H., Bulger, E. M., Duber, H. C., Greninger, A. L., Ong, T. D., Morris, S. C., Chew, L. D., Haffner, T. M., Sakata, V. L., dan Lynch, J. B. (2020) 'Western Washington State COVID-19 Experience: Keys to Flattening the Curve and Effective Health System Response', Journal of the American College of Surgeons. doi: 10.1016/j.jamcollsurg.2020.06.006.

Shen, C., Tan, M., Song, X., Zhang, G., Liang, J., Yu, H., dan Wang, C. (2020) 'Comparative Analysis of Early-Stage Clinical Features Between COVID-19 and

Influenza A H1N1 Virus Pneumonia', Frontiers in Public Health, 8, pp. 1-7. doi: 10.3389/fpubh.2020.00206.

Liu, Z., Bing, X., dan Zhi, X. Z. (2020) 'An Update on The Epidemiological Characteristics of Novel Coronavirus Pneumonia (COVID-19)', Chinese Journal of Epidemiology, 41(2), pp. 139-144. doi: 10.3760/cma.j.issn.0254-6450.2020.02.002.

WHO (2020) Novel Coronavirus - China. Available at: https://www.who.int/csr/don/12-january-2020novel-coronavirus-china/en/ (Accessed: 26 June 2020).

WHO (2020) Pertanyaan dan Jawaban: Pelacakan kontak untuk COVID-19, World health Organization. Available at: https://www.who.int/indonesia/news/novel-coronavirus/qa-contact-tracing (Accessed: 8 August 2020).

WHO (2020) WHO Director-General's Opening Remarks At the Media Briefing on COVID-19 - 11 March 2020, WHO Director General's speeches. Available at: https://www.who.int/dg/speeches/detail/who-director-general-s-opening-remarks-at-the-mediabriefing-on-covid-19 11-march-2020 (Accessed: 27 June 2020).

Worldometer (2020) Coronavirus Update (Live): COVID-19 Coronavirus Pandemic - Worldometer. Available at: https://www.worldometers.info/coronavirus/ (Accessed: 9 July 2020). 